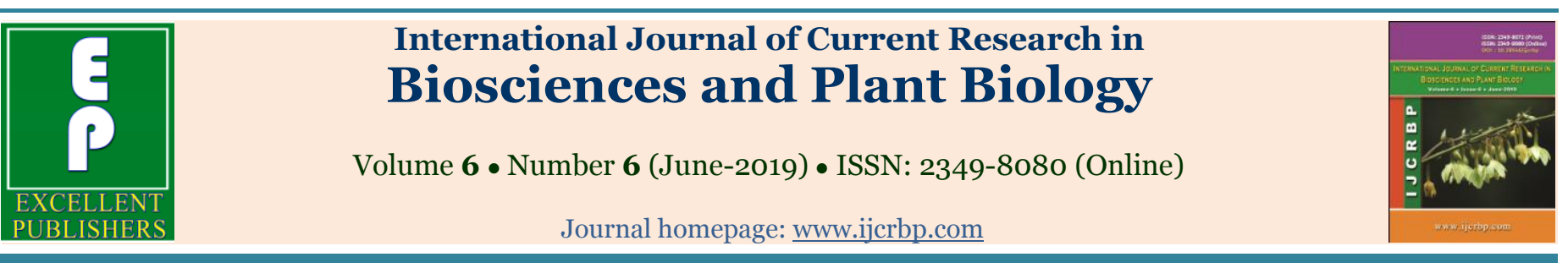

\title{
Effect of plant based soya milk extender on Bcl-2 family proteins in cryopreserved Murrah buffalo spermatozoa
}

\author{
R. Mohan ${ }^{*}$, H. Batra ${ }^{2}$ and S. K. Atreja3 \\ ${ }^{1}$ Assistant Professor, Institute of Integrated \& Honors Studies, Kurukshetra University, Kurukshetra, Haryana 136119, India \\ ${ }^{2}$ Senior Research Fellow, ABC Division, National Dairy Research Institute, Karnal, Haryana, India \\ 3 Principal Scientist, ABC Division, National Dairy Research Institute, Karnal, Haryana, India \\ *Corresponding author; e-mail: radhika.mohanndri@gmail.com
}

\begin{tabular}{|c|c|}
\hline Arti & ABSTRACT \\
\hline $\begin{array}{l}\text { Date } \\
27 \mathrm{M}\end{array}$ & \multirow{7}{*}{$\begin{array}{l}\text { The study was designed to investigate the effect of plant based soya milk Tris (SMT)- } \\
\text { extender used for cryopreservation of buffalo (Bubalus bubalis) spermatozoa on the } \\
\text { expression of Bcl-2 family proteins that regulates the susceptibility of cells to apoptosis. } \\
\text { Fresh buffalo semen (control without dilution) was cryopreserved in conventional EYT } \\
\text { ( } 20 \% \text { egg yolk v/v in Tris) and SMT ( } 25 \% \text { soya milk v/v in Tris) extender and used for } \\
\text { the assessment of expression of Bcl-2 family proteins. Proteins extracted from a total } \\
\text { number of nine ejaculates from three individual buffalo bulls chosen at random were } \\
\text { separated using SDS-PAGE followed by immunoblotting against Bcl-2, Bcl-xl, Bax and } \\
\text { Bak. In addition, comet assay was performed to compare sperm DNA integrity in frozen } \\
\text { thawed semen samples. The obtained results indicated a significant (p < o.o5) } \\
\text { reduction in the expression of Bcl-2, Bax and Bak in cryopreserved semen samples. The } \\
\text { results clearly demonstrated a significant (p<0.05) higher expression of Bcl-2 protein } \\
\text { in SMT extender as compared to EYT extender indicating its better resistance to } \\
\text { cryodamage. }\end{array}$} \\
\hline $\begin{array}{l}\text { Date } \\
06 \mathrm{~J}\end{array}$ & \\
\hline Key & \\
\hline & \\
\hline & \\
\hline & \\
\hline & \\
\hline
\end{tabular}

\section{Introduction}

Tris based-Egg yolk extender is largely accepted semen extender used for cryopreservation in domestic animals. It contains upto 20\% egg yolk which introduces a risk of microbial contamination and viral infections (Aires et al., 2003). Several studies have reported that use of plant based extenders show competitive results on various quality assessment parameters such as post thaw motility, viability and membrane integrity over egg yolk based extender (Hinsch et al., 1997). In our previous study (Mohan and Atreja, 2014), it was found that buffalo semen cryopreserved in non animal origin based Soya Milk Tris (SMT) phytoextender reduces the expression of apoptotic proteins such as caspases-3,-7,-9 and cytochrome c which helps in maintaining the mitochondrial membrane potential in comparison to Egg Yolk Tris (EYT) extender.

However, the Bcl-2 family proteins that includes pro-apoptotic (Bax and Bak) as well as antiapoptotic (Bcl-2 and Bcl-xl) factors have not been found and compared in Murrah buffalo spermatozoa cryopreserved in plant based SMT extender to EYT extenders as yet. Bcl-2 family proteins are the potent regulators of apoptosis that 
influence the permeability of the outer mitochondrial membrane. A study has reported the presence of pro-apoptotic factors Bax and absence of the anti-apoptotic factor Bcl-2 in bovine spermatozoa during cryopreservation (Martin et al., 2007). Another study on boar semen has shown significant higher levels of pro-apoptotic transcripts were associated with $\alpha$-tocopherol supplemented frozen-thawed sperm compared to fresh sperm. In contrast, the anti-apoptotic transcripts exhibited lower abundance in frozenthawed sperm compared to fresh sperm, suggesting that cryopreservation induced apoptosis extensively (Jeong et al., 2009). The expression levels of Bax can determine whether cell survival or cell death takes places and the Bcl2/Bax ratio is considered as an indicator of antiapoptotic effects (Adams and Cory, 1998).

The objective of the present study was to detect the presence of Bcl-2 family proteins in cryopreserved Murrah buffalo sperm and compare the protein expression in SMT and EYT extenders.

\section{Materials and methods}

\section{Semen collection and cryopreservation}

The Murrah buffalo (Bubalus bubalis) bulls (3-5 years of age) were maintained at Artificial Breeding Research Centre, NDRI, Karnal, India, under uniform nutritional conditions. A total number of six ejaculates were collected using an artificial vagina (IMV, L'Aiglecedex, France) from bulls chosen at random. Tubes containing ejaculates were immersed in a water bath maintained at $38.5^{\circ} \mathrm{C}$ until semen was extended. The semen was assessed immediately for mass activity and progressive motility by phase-contrast microscopy. Semen sample having the score of +3 or higher mass activity and $>80 \%$ progressive motility was used in this study. Each ejaculate was split into three aliquots, and one aliquot was used for fresh semen analysis (taken as control). Other aliquots were diluted in egg yolk tris (EYT) extender (20\% egg yolk (v/v) , $274 \mathrm{mM}$ Tris, $87 \mathrm{mM}$ Citric acid, 43 $\mathrm{mM}$ Glucose, 10 oo ooo IU Benzyl penicillin per litre, 7,50,000 IU Streptomycin per litre and 6.4\% Glycerol) and in Soya milk (25\% v/v replaced in Tris base extender) to a final cell concentration of $100 \times 10^{6}$ cells / ml (Mohan and Atreja, 2014). Diluted samples were aspirated into medium-sized
(0.25 ml) polypropylene French straws, sealed by a sealer machine (IMV, France) equilibrated at $4^{\circ} \mathrm{C}$ for 4 hours. After equilibration, straws were frozen into liquid nitrogen vapour, $5 \mathrm{~cm}$ above liquid nitrogen for 10 minutes and then straws were plunged into liquid nitrogen for storage. After storage for 3-4 weeks, frozen straws were then thawed at $37^{\circ} \mathrm{C}$ for 30 seconds in a water bath and used for the study of different semen parameters

\section{Semen processing}

Freshly ejaculated and frozen-thawed semen (500 $\mu \mathrm{l})$ was taken separately into $15 \mathrm{ml}$ polypropylene conical centrifuge tubes having $3 \mathrm{ml}$ of sp-TALPH (Modified Tyrode's Hepes-buffered medium- $\mathrm{pH}$ 7.4-7.45, osmolarity: 280-285 mosmol $/ \mathrm{kg}$ ) and centrifuged at $275 \times \mathrm{g}$ for 6 minutes for three times to remove the seminal plasma and extenders from the samples respectively. The pellet was resuspended in sp-TALPH, and sperm concentration was adjusted to $100 \times 10^{6}$ cells / ml with sp-TALPH by using haemocytometer.

\section{Sperm quality assessment}

Sperm motility, viability, membrane integrity, mitochondrial membrane potential and apoptosis in fresh and frozen thawed sample was detected by the method of (Mohan and Atreja, 2014). Briefly, phase contrast microscope was used for the assessment of motility, viability and integrity. Mitochondrial membrane potential and apoptosis was detected by $\mathrm{JC}-1$ and Annexin V-FITC/PI assay using fluorescent microscope (Bx-51; Olympus). At least 200 spermatozoa were counted per slide. The mean of observations was taken as the final score.

\section{Comet assay}

Sperm DNA integrity was analysed by comet assay in cryopreserved buffalo spermatozoa by method of (Singh et al., 1988). 85\% of live cells were collected by swim up procedure in both fresh and cryopreserved spermatozoa. The puffy layer was taken in a $15 \mathrm{~mL}$ test tube and processed with SpTALP medium. Cells were counted and set to $100 \times$ $10^{6}$ after final washing. Slides were then precoated with $1 \%$ normal melting point agarose. Then it was allowed to cool off, and again coated with $0.75 \%$ and $1 \%$ low melting point agarose. Slides were then immersed in lysing solution-I (1.25 M NaCl, 50 
mM EDTA, $100 \mathrm{mM}$ Tris base, $2 \mathrm{mg} / \mathrm{mL}$ reduced glutathione and $0.05 \mathrm{mg} / \mathrm{mL}$ DNAse free proteinase $\mathrm{K}, \mathrm{pH}$ 10.0) and lysing solution-II (1.25 $\mathrm{M} \mathrm{NaCl}, 50 \mathrm{mM}$ EDTA, $100 \mathrm{Mm}$ Tris base, $1 \% \beta-$ mercaptoethanol, $1 \%$ Triton $\mathrm{X}-100, \mathrm{pH} 10.0$ ) and incubated for $3 \mathrm{~h}$ and $5 \mathrm{~h}$ at $4^{\circ} \mathrm{C}$ respectively. They were put into the horizontal electrophoresis apparatus in chilled electrode buffer $(500 \mathrm{mM}$ $\mathrm{NaCl}$, $0.1 \mathrm{M}$ Tris-Base, $1 \mathrm{mM}$ EDTA, 0.2\% DMSO, $\mathrm{pH}$ 9.0) for chromatin decondensation and run at $24 \mathrm{~V}$ for $1 \mathrm{~h}$. And there after neutralized with neutralization buffer (20 mM Tris, $\mathrm{pH} 7.4$ ). The slides were then incubated in PBS buffer containing ethidium bromide (0.01\%) for $10 \mathrm{~min}$ and visualized under the fluorescent microscope (Bx-Olympus). Results were calculated by visual scoring and 200 cells were counted on the field.

\section{Identification of Bcl-2 family proteins in fresh and cryopreserved buffalo spermatozoa}

\section{Protein extraction}

Modified method of Galantino-Homer et al. (1997) was used to extract sperm proteins from the treated groups for 1-dimensional gel electrophoresis. Briefly, cell pellets washed in PBS were prepared in cell lysis buffer containing $3 \mu \mathrm{l}$ of $100 \mathrm{mM} \mathrm{Na}_{3} \mathrm{VO}_{4}, 3 \mu \mathrm{l}$ of protease inhibitor and 150 $\mu \mathrm{l}$ of SDS non-reducing sample buffer (0.0625 Tris-HCL, pH 6.8, 2\% SDS, 10\% glycerol) and subjected to hot lysis. After centrifugation at 14000 $\mathrm{rpm}$ for 10 minutes at $20^{\circ} \mathrm{C}$, supernatant was taken and the total protein was analyzed by the method of Lowry et al. (1951)

\section{SDS-PAGE and Immunoblotting}

For one dimensional gel electrophoresis, ten microgram of total cell lysate was loaded and resolved by SDS-PAGE using stacking and resolving gels with $4.5 \%$ and $10 \%$ of acrylamide, respectively. Pre-stained proteins with a broad range were used as molecular weight markers (BioRad, Hercules, CA, USA). Separated proteins were transferred to Immobilon-P-PVDF membrane adopting a two-step transfer method of Otter et al. (1987). Protein equal loading and transfer efficiency was tested by staining the membrane with $0.5 \%$ Ponceau S dye in $1 \%$ glacial acetic acid (Salinovich and Montelaro, 1986) and was also analyzed by the transfer of pre-stained molecular weight marker onto the PVDF membrane. The membrane was then blocked with $5 \%(\mathrm{w} / \mathrm{v})$ non-fat dried milk prepared in Tris buffered saline with Tween-20 (TBS-T: 20 mMTris, $150 \mathrm{mM} \mathrm{NaCl}$, 0.1\% (v/v) Tween-20, $\mathrm{pH} 7.6$ ) for overnight at $4^{\circ} \mathrm{C}$. The blocked membrane was incubated with anti-Bcl-2 (1:1000), anti-Bcl-xl (1:1000), anti-Bax (1:1000) and anti-Bcl-xl (1:1000) diluted in TBS-T), for $4 \mathrm{~h}$ at room temperature with intermittent gentle agitation. After subsequent washing in TBS-T, the membrane was incubated with goat anti-mouse IgG-HRP and anti-rabbit IgG-HRP conjugate (Santa Cruz Biotechnology) diluted (1:20,000) in TBS-T for 1 hour at room temperature with intermittent gentle agitation. Subsequently, the peroxidase activity was visualized by Immobilon Western Blotting chemiluminescent detection reagents (Millipore Corporation, Billerica, MA 01821 USA) according to manufacturer's instruction using Kodak X-OMAT-AR X-ray films.

\section{Densitometric analysis}

After chemiluminescence detection, the X-ray films were photographed by an image analysis (Image Scanner III, (GE-Healthcare, Biorkgatan, Uppsalla, Sweden), and densitometric analysis was performed with Multi Gauge analysis software (AlphaInnotech $囚 \mathrm{HP}$, Alphainnotech Corporation, San Leandro, CA, USA). To detect the integrative density of protein spots/bands on enhanced chemiluminescence (ECL) X-ray film digitized image was opened in Multi Gauge analysis software, protein bands were probed in a rectangular selection tool with constant pixel area, and integrative density value (IDV) calculated by the software was recorded. To determine the relative changes in the intensities of protein spots/bands, the intensity obtained with the control spermatozoa was assigned base value of 100 .

\section{Statistical Analysis}

All the experiments were done in six replicates i.e., a total of six semen ejaculates from six individual bulls chosen at random. Data were analysed by one-way analysis of variance (ANOVA) using the Statistical Product and Service Solutions, version 17.0.1 software (SPSS Inc., Chicago, IL, USA). Post hoc comparisons (Tukey Test) of least significant differences were evaluated between sample 
treatments. Results were expressed as the mean \pm standard error of the mean. A difference with mean at $\mathrm{p}<0.05$ was considered statistically significant.

\section{Results}

\section{Sperm quality assessment of freshly ejaculated and cryopreserved spermatozoa}

Cryopreservation process significantly $(\mathrm{p}<0.05)$ reduced the motility (fresh: $82 \pm 1.52$, cryopreserved, (EYT) 42.66 \pm 1.80 ; (SMT) 40.66 \pm 0.88 ), viability (fresh: 89.33 \pm 2.60 , cryopreserved (EYT) 58.73 \pm 1.66 ; (SMT) $59.33 \pm 2.60$ ) and membrane integrity (fresh: 74 \pm 1.52 , cryopreserved (EYT) 40 \pm 0.88 ; (SMT) 42 \pm 1.52 ) in buffalo spermatozoa. However the sperm quality parameters were comparable and did not show any statistically significant $(\mathrm{p}<0.05)$ difference between the EYT and SMT extenders. A significant $(\mathrm{p}<0.05)$ increase in the number of apoptotic (before $4.88 \pm 0.9$ vs. after freezing $44.64 \pm 1.8$ in EYT, $34.13 \pm 1.8$ in SMT) sperm cells with low mitochondrial potential (before 24.96 \pm 1.49 vs. after freezing $34.76 \pm 4.09$ in EYT, 28.33 \pm 0.88 ) was observed after cryopreservation process.

\section{Effect of SMT extender on sperm DNA integrity}

Comet assay was used to assess the DNA damage in fresh and cryopreserved spermatozoa (Fig. 1). DNA damage was observed both in freshly ejaculated and cryopreserved semen. Several subpopulations of comets were found, from minimum to maximum DNA damage as shown in Fig. 1. Scoring of comets revealed that in fresh samples, sperm DNA damage varied from an average of $10 \%$ which was significantly lower ( $p<0.01)$ as compared to the frozen-thawed spermatozoa. However, cryopreservation process significantly $(\mathrm{p}<0.01)$ increased the mean percentage of DNA damage (comets) up to $32.25 \%$ buffalo semen cryopreserved in Egg yolk tris based extender. The mean percentage of comets non-significantly increased ( $p>0.01)$ up to $34.75 \%$ in buffalo semen cryopreserved in Soya milk tris based extender as shown in graph Fig. 1. The difference in the mean percentage of comets (DNA strand breaks) between the two extenders (EYT and SMT) was statistically non-significant $(\mathrm{p}>0.01)$.

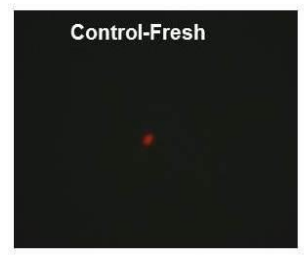

Cryopreserved-EYT

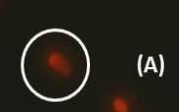

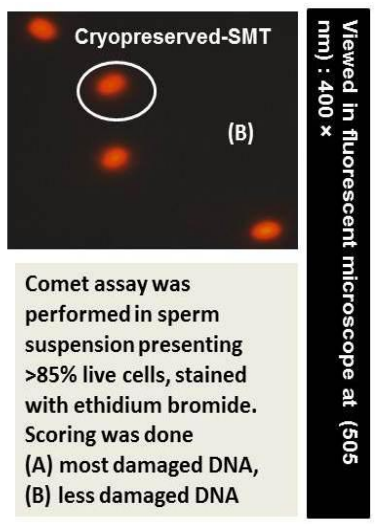
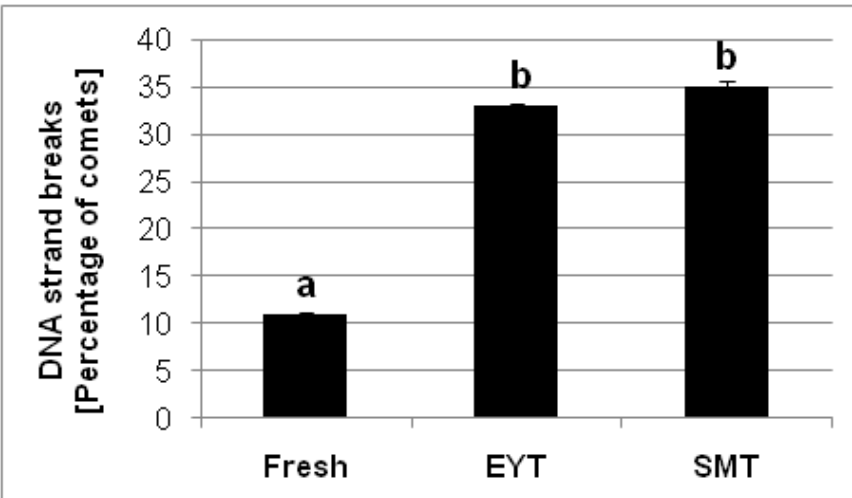

Fig. 1: DNA damage in cryopreserved buffalo [Bubalus bubalis] spermatozoa. Comet assay was performed in sperm suspension representing $>85 \%$ live cells stained with ethidium bromide and slides were observed under fluorescent microscope at 400× magnification. Graph represents the effect of cryopreservation on DNA integrity in fresh and cryopreserved semen. Values are the means \pm SEM of three experiments. Different letters are significantly different at $\mathrm{p}<0.01$.

\section{Effect of SMT extender on Bcl-2 family proteins}

Fig. 2 shows the presence of $26 \mathrm{kDa}$ antiapoptotic Bcl-2 protein was in fresh spermatozoa. The bands were observed at $26 \mathrm{kDa}$ for Bcl-2 protein. A dimer at $55 \mathrm{kDa}$ was also observed. The increase in concentration of protein lysate from $10 \mu \mathrm{g}$ to $15 \mu \mathrm{g}$ also showed the increase in band intensity of Bcl-2 protein as shown in Fig. 2. Cryopreservation significantly $(p<0.05)$ reduced the band intensity of Bcl-2 protein in buffalo spermatozoa as compared to fresh semen samples as shown in Table 1. Moreover, the cryopreservation in SMT extender showed a significant $(\mathrm{p}<0.05)$ increase in band intensity (60.11 \pm 5.55$)$ of $\mathrm{Bcl}-2$ protein in comparison to EYT extender (52.55 \pm 1.90 , Table 1$)$. 
Table 1. Relative band intensities of Bcl-2 family proteins detected in cryopreserved buffalo (Bubalus bubalis) spermatozoa. Control (fresh semen) was taken as 100\%. Values are the means \pm Standard Error Mean [S.E.M.] of three experiments. Means with different letters $[\mathrm{a}, \mathrm{b}, \mathrm{c}]$ indicate significant $[\mathrm{p}<0.05]$ differences.

\begin{tabular}{lllll}
\hline $\begin{array}{l}\text { Name of } \\
\text { protein }\end{array}$ & $\begin{array}{l}\text { Mol. Mass of the } \\
\text { detected proteins/ } \\
\text { subunits (kDa) }\end{array}$ & $\begin{array}{l}\text { Control buffalo } \\
\text { spermatozoa } \\
\text { (Fresh sample) }\end{array}$ & $\begin{array}{l}\text { Spermatozoa } \\
\text { cryopreserved in } \\
\text { egg yolk tris } \\
\text { extender (EYT) }\end{array}$ & $\begin{array}{l}\text { Spermatozoa } \\
\text { cryopreserved in } \\
\text { soya-milk tris } \\
\text { extender (SMT) }\end{array}$ \\
\hline $\mathrm{Bcl}-2$ & $26 \mathrm{kDa}$ & $100^{\mathrm{a}}$ & $52.55 \pm 1.90^{\mathrm{b}}$ & $60.11 \pm 5.55^{\mathrm{c}}$ \\
$\mathrm{Bax}$ & $50 \mathrm{kDa}$ & $100^{\mathrm{a}}$ & $8.32 \pm 1.4^{\mathrm{b}}$ & $10.07 \pm 0.07^{\mathrm{b}}$ \\
$\mathrm{Bax}$ & $30 \mathrm{kDa}$ & $100^{\mathrm{a}}$ & $2.25 \pm 0.73^{\mathrm{b}}$ & $0.00^{\mathrm{b}}$ \\
\hline
\end{tabular}
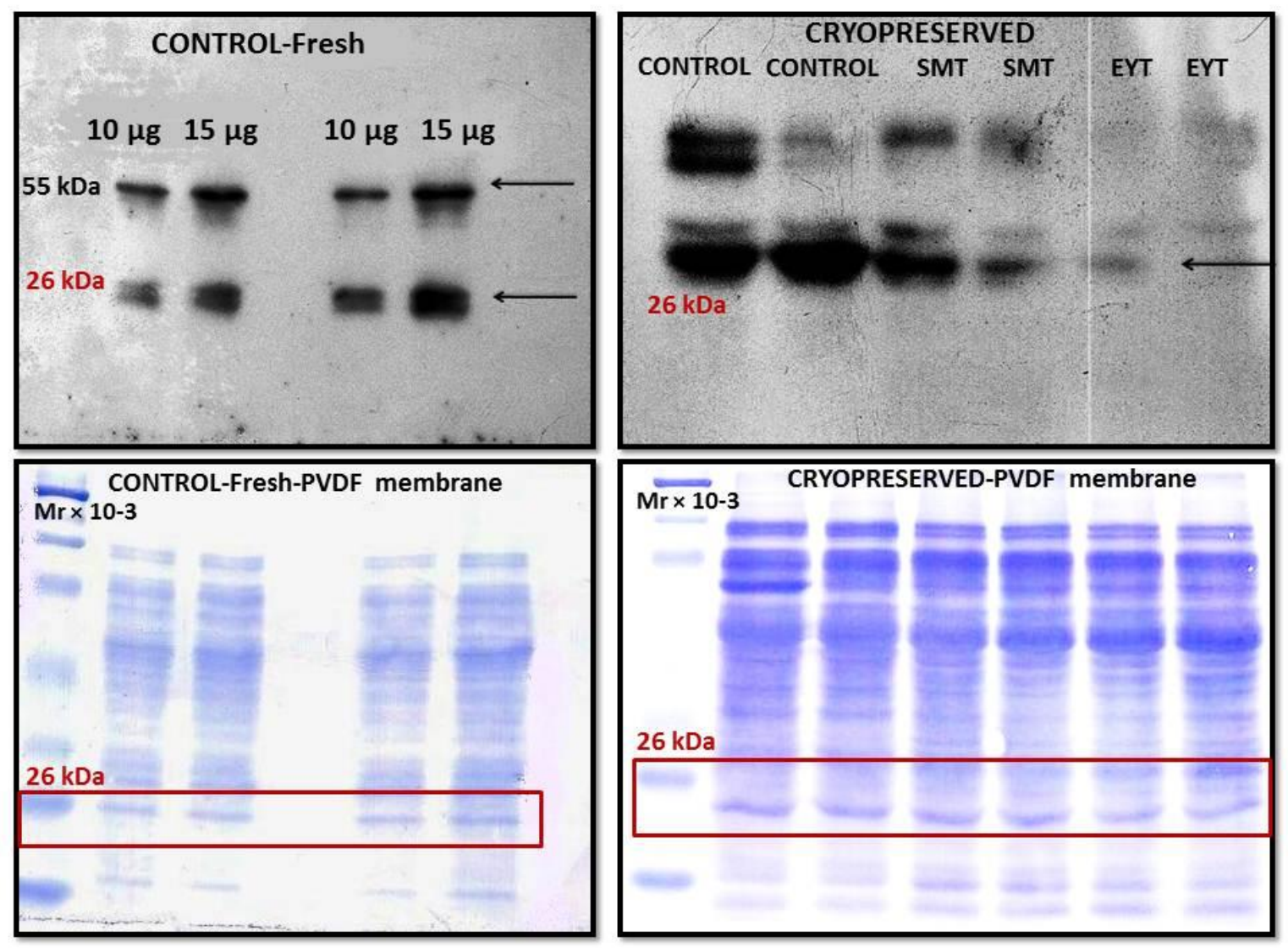

Fig. 2: Detection of Bcl-2 protein [anti-apoptotic] in buffalo [Bubalus bubalis] spermatozoa by immunoblotting. Control represents freshly ejaculated spermatozoa and frozen thawed semen in EYT [egg-yolk tris] extender and SMT [soya-milk tris] extender respectively. Total proteins were extracted and resolved in 10\% uniform SDS-PAGE [10 $\mu \mathrm{g} /$ lane] and electrotransferred on to a polyvinylidine difluoride membrane followed by detection using specific mouse monoclonal antibody [sc-7382]. Membranes were subsequently stained with Coomassie Brilliant Blue R-250 as per the procedures outlined in Materials and Methods. $\mathrm{Mr} \times 1 \mathrm{O}^{-3}$ represents the position of the relative molecular mass standards.

The result in Fig. 3 depicts the immunoblot for anti-apoptotic Bcl-xl protein which was not detected in fresh and cryopreserved samples. Although non-specific bands were found but no signal was observed at $30 \mathrm{kDa}$ which is the molecular weight of Bcl-xl protein. Fig. 3 shows a $30 \mathrm{kDa}$ pro-apoptotic protein Bak which was detected in fresh buffalo spermatozoa but its band intensity was significantly $(\mathrm{p}<0.05)$ reduced in cryopreserved (EYT and SMT extenders, Table 1) buffalo spermatozoa.

A $21 \mathrm{kDa}$ pro-apoptotic Bax protein with a dimer at $42 \mathrm{kDa}$ was found in fresh sample as shown in 
Fig. 4. Cryopreservation of buffalo spermatozoa significantly $(\mathrm{p}<0.05)$ reduced the band intensity
(Table 1) of Bax protein in both EYT and SMT extender in comparison to fresh samples (Fig. 4).
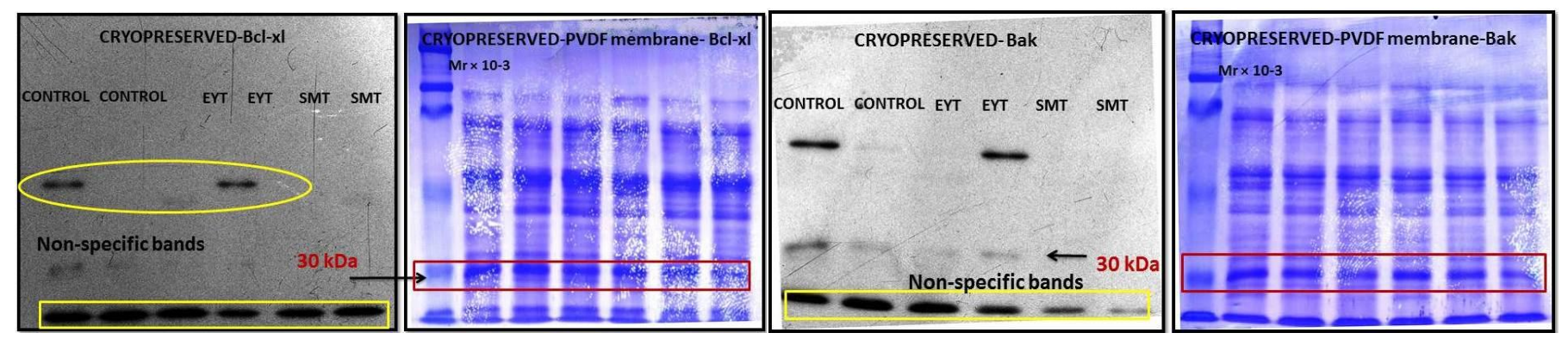

Fig. 3: Detection of Bcl-xl [anti-apoptotic] and Bak [pro-apoptotic] proteins in buffalo [Bubalus bubalis] spermatozoa by immunoblotting. Control represents freshly ejaculated spermatozoa and frozen thawed semen in EYT [egg-yolk tris] extender and SMT [soya-milk tris] extender respectively. Total proteins were extracted and resolved in $10 \%$ uniform SDS-PAGE [10 $\mu \mathrm{g} /$ lane] and electrotransferred on to a polyvinylidinedifluoride membrane followed by detection using rabbit polyclonal antibody [sc-7195 for Bcl-xl and sc-7873 for Bak].Non -specific bands are encircled in yellow.
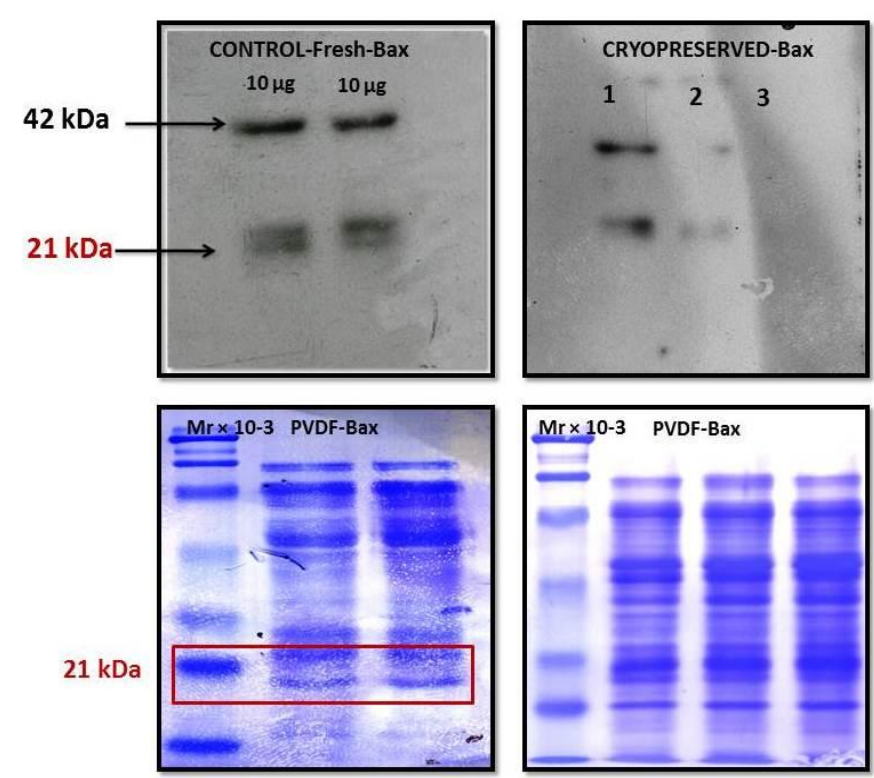

Fig. 4: Detection of Bax protein [pro-apoptotic] in buffalo [Bubalus bubalis] spermatozoa by immunoblotting using Monoclonal Anti-Bax Clone 2D2 [Sigma- B-8554] antibody. Lane-1 represents protein lysates of control-freshly ejaculated spermatozoa and cryopreserved semen in Lane-2- EYT [egg-yolk tris] extender and Lane-3-SMT [soya-milk tris] extender respectively. Total proteins were extracted and resolved in $10 \%$ uniform SDS-PAGE [10 $\mu \mathrm{g} /$ lane] and electrotransferred on to a polyvinylidine difluoride membrane subsequently stained with Coomassie Brilliant Blue R-250.

\section{Discussion}

The pro-apoptotic and anti-apoptotic members of the Bcl-2 family act as a marker upstream of caspases and mitochondrial dysfunction which promotes and inhibits apoptosis, respectively (Chao and Korsmeyer, 1998). Not only, these proteins have long been known to play a role in protecting the cells from physical and chemical damage, they also have a more direct role in suppressing the apoptosis in cells. A $26 \mathrm{kDa}$ antiapoptotic protein- Bcl-2 was found in our study. The results (Fig. 2) revealed a significantly $(p<0.05)$ higher levels of anti-apoptotic Bcl-2 protein was found in fresh samples in comparison to frozen-thawed samples in SMT and EYT extenders. It suggests that freezing and thawing might possibly be degrading the Bcl-2 protein. However, a significantly $(\mathrm{p}<0.05)$ higher band intensity for Bcl-2 protein was observed in SMT extender as compared to EYT extender (Table 1). Furthermore, anti-apoptotic Bcl-2 members sequester pro-apoptotic Bcl-2 members by binding to their $\mathrm{BH}_{3}$-domains and thereby, ultimately prevent Bax or Bak activation/ oligomerization and mitochondrial pore formation. The over expression of Bcl-2l or Bcl-xl potently inhibits apoptosis in response to many cytotoxic insults (Oltvai et al., 1993).

The present study shows the expression of dimers at $55 \mathrm{kDa}$ for Bcl-2 protein (Fig. 2). A study in bovine semen has reported the absence of antiapoptotic Bcl-2 protein in fresh and cryopreserved samples (Martin et al., 2007). The presence of low level of Bcl-2, if any is known to protect mitochondria from pore formation (Martin et al., 2007). In our study, detection of Bcl-2 expression 
suggests that the mitochondria in both fresh and cryopreserved Murrah buffalo spermatozoa appear less sensitive to the cryopreservation process in comparison to bovine spermatozoa.

The results also show the presence of significantly $(\mathrm{p}<0.05)$ higher expression of pro-apoptotic proteins Bax (21 kDa) and Bak (30kDa) proteins in fresh samples as compared to frozen thawed samples in SMT and EYT extender. The proapoptotic regulatory factors, Bax and Bak induce caspase-dependent DNA degradation after inducing the release of cytochrome $\mathrm{c}$ from mitochondrial membranes. The comet assay results (Fig. 1) in this study show a significant amount of DNA damage in cryopreserved (both SMT and EYT) spermatozoa in comparison to fresh samples. These results are in agreement with earlier reports indicating the increase in sperm DNA fragmentation in cryopreserved boar spermatozoa (Fraser and Strzezek, 2005). However, the cryopreservation in SMT extender was found to have a statistically non-significant, p>0.01, but more damage to sperm DNA integrity as compared to EYT extender.

Although, Bax, Bak and Bcl-2 proteins significantly $(\mathrm{p}<0.05)$ reduced after cryopreservation, but the expression of Bcl-2 protein was found to be significantly $(\mathrm{p}<0.05)$ higher in SMT extender in comparison to EYT extender. In conclusion, the higher expression of Bcl-2 protein in SMT-frozenthawed semen suggests its ability to block apoptosis and it confirms better resistance in comparison to EYT extender which is also in agreement to our previous study (Mohan and Atreja, 2104). This also suggests, the ability of sperm for prolonged survival during cryopreservation may be correlated with the counterbalancing of pro- and anti-apoptotic proteins.

\section{Acknowledgement}

The authors sincerely thank of Artificial Breeding Research Centre (ABRC), ICAR-NDRI, Karnal for providing assistance in collecting semen samples.

\section{Conflict of interest statement}

Authors declare that they have no conflict of interest.

\section{References}

Adam, J.M., Cory, S., 1998. The Bcl-2 protein family: arbiters of cell survival. Science. 281, 1322-1326.

Aires, J.M., Hinsch, K.D., Mueller-Schloesser, F., Bogner, K., Mueller Schloesser, S., Hinsch, E., 2003. In vitro and in vivo comparison of egg yolk-based and soybean lecithin-based extenders for cryopreservation of bovine semen. Theriogenology. 60, 269-279.

Chao, D.T., Korsmeyer, S.J.,1998. Bcl-2 family: regulators of cell death. Ann. Rev. Immunol. 16, 395-419.

Fraser, L., Strzezek, J., 2005. Effects of freezingthawing on DNA integrity of boar spermatozoa assessed by the neutral comet assay. Reprod. Dom. Anim. 40, 530-536.

Galantino-Homer, H.L., Visconti, P.E., Kopf, G.S., 1997. Regulation of protein tyrosine phosphorylation during bovine sperm capacitation by a cyclic adenosine 3', 5'monophosphate-dependent pathway. Biol. Reprod. 56, 707-719.

Hinsch, E., Hinsch, K.D., Boehm, J.G., Schill, W.B., Mueller-Schloesser, F. 1997. Functional parameters and fertilization success of bovine semen cryopreserved in egg yolk-containing extenders. Reprod. Domest. Anim. 32,143-149.

Jeong , Y.J., Kim, M.K., Song, H.J., Kang, E.J., Ock, S.A., Kumar, B.M., Balasubramanian, S., Rho, G.J. 2009. Effect of a-tochopherol supplementation during boar semen cryopreservation on sperm characteristics and expression of apoptosis related genes. Cryobiology. 58, 181-189.

Lowry, O.H., Rosebrough, N.J., Farr, A.L., Randall, R.J., 1951. Protein measurement with the folin phenol reagent. J. Biol. Chem. 193, 265-275.

Martin, G., Cagnon, N., Sabido, O., Sion, B., Grizard, G., Durand, P., Levy, R., 2007. Kinetics of occurrence of some features of apoptosis during the cryopreservation process of bovine spermatozoa. Hum. Reprod. 22, 380388.

Mohan, R., Atreja, S.K., 2014. Soya milk tris-based phytoextender reduces apoptosis in cryopreserved Buffalo (Bubalus bubalis) spermatozoa. Reprod. Domest. Anim. 49, 797805.

Oltvai, Z.N., Milliman, C.L., Korsmeyer, S.J. 1993. Bcl-2 heterodimerizes in vivo with a conserved 
homolog, Bax that accelerates programmed cell death. Cell. 74, 609-619.

Otter, T., King, S.M., Witman, G.B., 1987. A two step procedure for efficient transfer of both high-molecular weight (greater than 400,000) and low molecular weight (less than 20,000) proteins. Anal. Biochem. 162, 370-377.

Salinovich, O., Montelaro, R.C., 1986. Reversible staining and peptide mapping of proteins transferred to nitrocellulose after separation by sodium dodecyl sulfate polyacrylamide gel electrophoresis. Anal. Biochem. 156, 341-347.

Singh, N.P., McCoy, M.T., Tice, R.R., Schneider, E.L., 1988. A simple technique for quantitation of low levels of DNA damage in individual cells. Exp. Cell. Res. 175, 184-191.

\section{How to cite this article:}

Mohan, R., Batra, H., Atreja, S. K., 2019. Effect of plant based soya milk extender on Bcl-2 family proteins in cryopreserved Murrah buffalo spermatozoa. Int. J. Curr. Res. Biosci. Plant Biol. 6(6), 34-41.

doi: https://doi.org/10.20546/ijcrbp.2019.606.005 